\title{
PENGARUH EVALUASI TES FORMATIF TERHADAP HASIL BELAJAR MATEMATIKA DITINJAU DARI TINGKAT KEMANDIRIAN BELAJAR MAHASISWA STT-PLN JAKARTA DENGAN MENGGUNAKAN ANALISIS VARIAN ANOVA
}

\author{
Dwi Anggaini' ${ }^{1)}$, Miftahul Fikri' ${ }^{2}$, Denny Setiawan ${ }^{3)}$ \\ Teknik Elektro, Sekolah Tinggi Teknik - PLN \\ 12 dwianggaini.da@gmail.com, ${ }^{2}$ miftahulfikri0@gmail.com, ${ }^{3}$ dennys03@gmail.com
}

\begin{abstract}
Research is a study that aims to find out the truth by researching and analyzing the influence of student learning independence in formative tests on student mathematics learning outcomes. The study was conducted at the Technical High School - PLN Jakarta in the even semester of 2017/2018 school year with a sample of 52 students using cluster random sampling technique. To retrieve data using questionnaire instruments to capture data on student learning independence variables and use tests to measure students' mathematics learning outcomes. Data analysis was performed using one-way ANOVA to prove the validity of the research hypothesis. Based on the results of the data analysis test, it can be concluded that there is an interaction between formative tests and students' learning independence towards mathematics learning outcomes and is directly proportional to learning independence.
\end{abstract}

Keywords: ANOVA, formative tests, cluster random, sample.

\begin{abstract}
ABSTRAK
Penelitian merupakan sebuah kajian yang bertujuan untuk menemukan kebenaran dengan meneliti dan menganalisa pengaruh kemandirian belajar mahasiswa dalam tes formatif terhadap hasil belajar matematika mahasiswa. Penelitian dilaksanakan di Sekolah Tinggi Teknik - PLN Jakarta pada semester genap tahun ajaran 2017/2018 dengan sampel 52 mahasiswa menggunakan teknik pengambilan sampel cluster random sampling. Untuk pengambilan data menggunakan instrumen angket untuk menjaring data pada variabel kemandirian belajar siswa dan menggunakan tes untuk mengukur hasil belajar matematika siswa. Analisis data dilakukan dengan menggunakan ANOVA satu jalur untuk membuktikan kebenaran hipotesis penelitian. Berdasarkan hasil uji analisis data dapat disimpulkan bahwa terdapat interaksi antara tes formatif dengan kemandirian belajar siswa terhadap hasil belajar matematika serta berbanding lurus dengan kemandirian belajar.
\end{abstract}

Kata kunci : ANOVA, tes formatif, cluster random, sampel. 


\section{PENDAHULUAN}

Pendidikan tinggi merupakan kelanjutan pendidikan menengah yang diselenggarakan untuk menyiapkan peserta didik menjadi anggota masyarakat yang memiliki kemampuan akademik dan/atau profesional yang dapat menerapkan, mengembangkan dan/atau menciptakan ilmu pengetahuan, teknologi dan/atau kesenian. Satuan pendidikan yang menyelenggarakan pendidikan tinggi disebut perguruan tinggi yang dapat berbentuk akademik, politeknik, sekolah tinggi, institut dan universitas.

Menurut Undang-Undang Republik Indonesia Nomor 20 Tahun 2003 tentang Sistem Pendidikan Nasional. Evaluasi hasil belajar peserta didik untuk memantau proses, kemajuan, dan perbaikan hasil belajar peserta didik secara berkesinambungan. Dalam ayat berikutnya evaluasi peserta didik, satuan pendidikan, dan program pendidikan dilakukan oleh lemabaga mandiri secara berkala, menyeluruh, transparan, dan sistemik untuk menilai pencapaian standar nasional pendidikan. Dari penjelasan undang-undang tersebut dapat ditarik kesimpulan bahwa bukan hanya seorang guru yang membutuhkan hasil dari mahasiswa, tetapi ada tujuan lain yang lebih besar yaitu untuk mencapai standar nasional pendidikan yang sudah ditentukan oleh negara melalui Kementrian Pendidikan Nasional dan Kebudayaan.

Faktor lain yang dapat meningkatkan hasil belajar adalah faktor kemandirian dalam belajar. Yang terpenting dalam kemandirian belajar ialah peningkatan kemampuan dan keterampilan mahasiswa dalam proses belajar tanpa bantuan orang lain, sehingga pada akhirnya mahasiswa tidak tergantung pada dosen, pembimbing, teman atau orang lain dalam belajar. Kemandirian akan tumbuh pada diri seseorang jika dalam dirinya telah memiliki motivasi yang tinggi akan pentingnya belajar. Sifat ketidaktergantungan pada orang lain menjadikan diri mahasiswa mandiri dan memiliki inisiatif yang baik untuk dapat menyelesaikan tugas-tugasnya dalam pembelajaran. Untuk membutuhkan sikap tersebut, dosen diharapkan dapat menciptakan kondisi belajar mengajar yang baik.

Jika kemandirian mahasiswa dapat ditumbuhkan maka kemandirian ini dapat bermanfaat bagi dirinya sendiri dan berefek pada sikap hidupnya sehari-hari di semua aktifitasnya. Kemandirian yang berkembang dengan baik sangat membantu peran dosen dan orang tuanya dalam menyelesaikan masalah belajar mahasiswa tersebut. Sehingga jika kemandirian mahasiswa telah terbentuk dan dosen dapat menerapkan bentuk evaluasi yang dapat meningkatkan kemandirian belajar mahasiswa.

Dalam penelitian ini peneliti hanya membatasi pada Sekolah Tinggi Teknik - PLN (STTPLN) dan peneliti akan membahas mengenai Pengaruh Evaluasi Tes Formatif Terhadap Hasil Belajar Matematika Ditinjau Dari Tingkat Kemandirian Belajar Mahasiswa STT-PLN Jakarta.

Dari latar belakang diatas, maka permasalahan tersebut dapat di rumuskan sebagai berikut:

1. Apakah terdapat pengaruh interaksi tes formatif dan tingkat kemandirian belajar mahasiswa terhadap hasil belajar matematika mahasiswa?

2. Apakah terdapat pengaruh hasil belajar matematika antara mahasiswa yang diberikan tes formatif yang memiliki tingkat kemandirian belajar yang tinggi?

3. Apakah terdapat pengaruh hasil belajar matematika antara mahasiswa yang diberikan tes formatif yang memiliki tingkat kemandirian belajar yang rendah?

\subsection{Tujuan dari penelitian ini adalah:}

1. Mengetahui pengaruh interaksi tes formatif dan tingkat kemandirian belajar mahasiswa terhadap hasil belajar matematika mahasiswa,

2. Mengetahui pengaruh hasil belajar matematika antara mahasiswa yang diberikan tes formatif yang memiliki tingkat kemandirian belajar yang tinggi,

3. Mengetahui pengaruh hasil belajar matematika antara mahasiswa yang diberikan tes formatif yang memiliki tingkat kemandirian belajar yang rendah. 


\subsection{Manfaat dari penelitian ini adalah:}

1. Meningkatkan tingkat kemandirian belajar mahasiwa sebagai salah satu faktor untuk meningkatkan hasil belajar mahasiswa untuk mata kuliah matematika khususnya dan mata kuliah lain secara umum.

2. Memberikan masukan untuk unit terkait di STT-PLN sebagai evaluasi hasil kegiatan belajar-mengajar.

\section{METODOLOGI PENELITIAN}

\subsection{Hasil Belajar Mengajar}

Tujuan utama pmebalajaran adalah memperoleh hasil belajar yang seoptimal mungkin. Untuk mengetahui tingkat keberhasilan suatu proses pembelajaran adalah dengan mengukurnya melalui tes-tes tertentu terhadap individu yang belajar. Hasil belajar matematika adalah hasil belajar yang diperoleh mahasiswa setelah belajar matematika. Pernyataan ini seperti dikemukakan oleh Briggs: hasil belajar adalah seluruh kecakapan dan hasil yang dicapai setelah proses belajar di sekolah yang dinyatakan dengan angka atau nilai yang diukur. Data kuantitatif merupakan suatu bukti kemampuan mahasiswa dalam belajar setelah mengikuti proses belajar matematika. Hasil belajar matematika merupakan penguasaan mahasiswa terhadap mata pelajaran matematika yang diberikan dalam periode waktu tertentu di sekolah.

Hasil belajar mahasiswa adalah sebuah prosedur sistematis yang menetapkan berapa banyak yang telah dipelajari seorang mahasiswa. Untuk memperoleh hasil belajar matematika yang maksimal mahasiswa harus mengerti konsep matematika, dapat melihat dan menyatakan hubungan antara konsep yang satu dengan konsep yang lainnya, dan dapat menurunkan sifat-sifatnya.

Penyajian atau pengungkapan butir-butir matematika yang akan disampaikan disesuaikan dengan perkiraan dan perkembangan intelektual peserta didik. Mahasiswa diharapkan mampu berfikir deduktif, namun dalam proses pembelajarannya dapat digunakan pola pikir induktif untuk menyesuaikan dengan tahap perkembangan intelektual mahasiswa. Matematika sekolah memperhatikan aspek kependidikannya, dapat terjadi penyederhanaan dari matematika yang kompleks. Disesuaikan dengan tingkat usia mahasiswa. Seorang guru harus berusaha untuk mengurangi sifat abstrak dari objek matematika itu sehingga memudahkan mahasiswa menangkap pelajaran matematika di sekolah. Dengan kata lain seorang matematika mengajarkan sesuai dengan perkembangan penalaran mahasiswanya, harus mengusahakan agar fakta, konsep, operasi, ataupun prinsip dalam matematika itu terlihat konkrit.

Dalam penelitian ini yang dimaksud dengan hasil belajar matematika adalah hasil belajar yang dieproleh mahasiswa setelah belajar matematika diukur dengan menggunakan tes terdiri dari sekumpulan pertanyaan yang harus dijawab atau tugas yang harus dikerjakan yang akan memberi informasi mengenai aspek berdasarkan jawaban terhadap pertanyaan-pertanyaan atau hasil subyek dalam melakukan tugas-tugas tersebut. Untuk memperoleh hasil belajar matematika yang maksimal mahasiswa harus mengerti konsep matematika, dapat melihat dan dapat menyatakan hubungan antara konsep yang satu dengan konsep yang lainnya, dapat mengurutkan sifat-sifatnya.

\subsection{Tingkat Kemandirian Mahasiswa}

Menurut Brookkfield bahwa konsep dasar dari kemandirian belajar adalah Self directed learning, self teaching, autonomous learning dan volunntary learning.

Konsep Belajar Mandiri (Self-directed Learning) artinya bahwa mahasiswa belajar dengan pengendalian diri. Hal imi sebenarnya berakar dari konsep pendidikan orang dewasa. Namun demikian berdasarkan beberapa penelitian yang dilakukan oleh para ahli seperti Garrison tahun 1997, Schillereff tahun 2001, dan Scheidet tahun 2003 ternyata belajar mandiri juga cocok untuk semua tingkatan usia. Dengan kata lain, belajar mandiri sesuai untuk semua jenjang sekolah baik untuk sekolah menegah maupun sekolah dasar dalam rangka meningkatkan prestasi dan kemampuan mahasiswa.

Self teaching artinya bahwa anak dapat mengajar dirinya sendiri melalui pengalamannya, baik pengalaman keberhasilan maupun pengalaman kegagalan. Pengalaman keberhasilan seringkali 
menjadi acuan dan pendorong bagi mahasiswa untuk belajar ke arah yang lebih baik lagi. Sebaliknya mahasiswa akan menghindarkan diri dari pengalaman kegagalan. Dengan demikian, pengalaman sangatlah berharga bagi mahasiswa sebagai acuan pada kegiatan belajar selanjutnya.

Autonomous learning artinya bahwa mahasiswa mampu memilih dan menetapkan batas materi pelajaran yang dipelajari. Dalam kegitan belajar, mahasiswa cenderung melakukannya sesuai dengan batas-batas keinginan yang diharapkan. Untuk memperoleh pengetahuan dan keterampilan mahasiswa tidak segan-segan mendalami pelajaran yang telah diperolehnya, baik secara mandiri maupun dengan bertanya kepada guru sebagai sumber belajar, namun sebelum bertanya kepada sumber belajar, mahasiswa terlebih dahulu berusaha untuk memahami apa yang dipelajarinya.

Voluntary learning artinya bahwa mahasiswa cenderung dengan tidak ada paksaan. Apabila adanya kesadaran akan pentingnya belajar maka mahasiswa dengan sendirinya akan melakukan aktivitas belajar tanpa adanya paksaan baik orangtua, guru, teman maupun siapapun. Aktivitas belajar akan muncul secara internal dari diri mahasiswa sebagai usaha dalam memenuhi kebutuhan, yaitu kebutuhan akan penguasaan pengetahuan dan keterampilan.

\subsection{Evaluasi Tes Formatif}

Tes, pengukuran dan penilaian merupakan tiga aspek yang saling berhubungan dalam kegiatan pemebalajaran. Tes merupakan alat ukur, pengukuran merupakan proses pemebrian angka yang bersifat kuantitatif dan penilaian merupakan proses pengambilan keputusan yang bersifat kualitatif berdasarkan hasil pengukuran.

Pengukuran adalah proses pemberian angka atau usaha memperoleh deskripsi numerik dari suatu tingkatan di mana seorang mahasiswa telah mencapai karekteristik tertentu. Pengukuran dalam bidang pendidikan sangatlah kompleks. Kemampuan dalam pengukuran ini dibutuhkan keahlian tersendiri. Oleh sebab itu, kemampuan dalam membuat tes dan melakukan pengukuran dan penilaian merupakan kemampuan profesional yang harus dimiliki oleh dosen.

Djaali dan Muljono menyatakan bahwa secara umum tes dapat diartikan sebagai alat yang digunakan untuk mengukur atau penguasaan objek ukur terhadap perangkat konten atau materi tertentu. Berdasarkan pendapat tersebut tes adalah alat ukur yang mampu mengemukakan kemampuan mahasiswa dalam penguasaan materi sehingga guru dapat mengetahui seberaoa besar kemampuan mahasiswa terhadap materi tertentu. Bruce seperti yang dikutip Djaali dan Muljono menyatakan bahwa tes dapat mengukur banyaknya pengetahuan yang diperoleh individu sari suatu bahan pelajaran yang terbatas pada tingkat tertentu. Azwar menyatakan bahwa tes tidak lain dari pada sekumpulan pertanyaan yang harus dijawab atau tugas yang harus dikerjakan yang akan memberikan informasi mengenai aspek psikologis tertentu berdasarkan jawaban terhadap pertanyaan-pertanyaan atau cara dan hasil subjek dalam melakukan tugas-tugas tersebut. Berdasarkan pendapat tersebut Tes adalah alat ukur yang didalamnya terdapat pertanyaanpertanyaan yang harus dijawab sebagai bahan ukur kemampuan mahasiswa dalam pelajaran matematika, hasil pengukurannya berupa data kuantitatif atau berupa angka. 


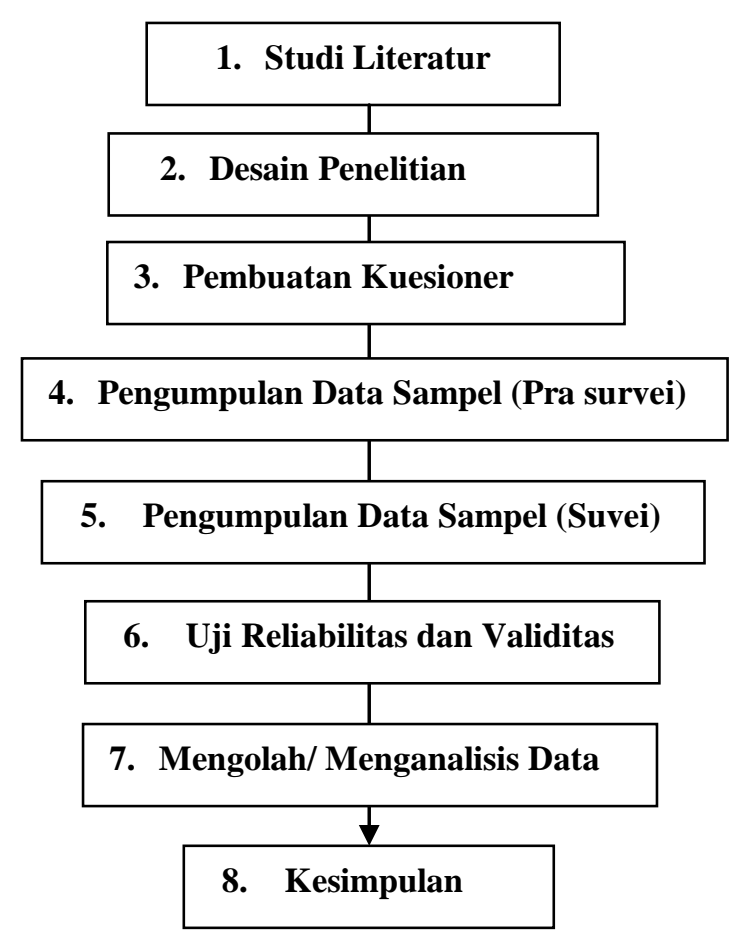

Gambar 1. Flowchart Metode Penelitian

\subsection{Pengumpulan Data Sampel}

Populasi adalah keseluruhan elemen yang menjadi perhatian dalam suatu penelitian. Menurut Sudjana populasi adalah totalitas semua nilai yang mungkin hasil menghitung ataupun pengukuran, kuantitatif maupun kualitiatif mengenai karakteristik tertentu dari senya anggota kumpulan yang lengkap dan jelas serta ingin dipelajari sifat-sifatnya.

Populasi pada penelitian ini adalah seluruh mahasiswa D-III Teknik Elektro STT-PLN dengan jumlah mahasiswa 427 mahasiswa yang terdaftar pada semester genap tahun ajaran 2017-2018. Sampel pada penelitian ini adalah sebanyak 80 mahasiswa D-III Teknik Elektro.

\subsection{Uji Reliabilitas}

Perhitungan reliabilitas digunakan untuk mengetahui taraf kepercayaan atau kehandalan suatu tes. Rumus yang digunakan adalah rumus Kuder-Richard son 20.

Keterangan:

$$
r_{k k}=\frac{k}{k-1}\left[1-\sum \frac{p q}{S t^{2}}\right]
$$

$r_{k k}:$ Koefisien reliabilitas

$k \quad$ : Banyak butir yang valid

$\Sigma p q:$ Jumlah varians skor butir

$S t^{2} \quad$ : Varians skor total

\subsection{Uji Validitas}

Validitas adalah suatu ukuran yang menunjukan tingkat-tingkat kevalidan atau kesahihan suatu instrumen. Validitas instrumen dilakukan untuk mengetahui sejauh mana suatu instrumen dapat mengukur apa yang seharusnya diukur.

Rumus yang digunakan adalah teknik korelasi Point Biserial 
Keterangan:

$$
r_{b i s(i)}=\frac{\bar{X} i-\bar{X} t}{S_{t}} \sqrt{\frac{P_{i}}{q_{i}}}
$$

$r_{b i s(i)}$ : Koefisien korelasi biserial skor butir dengan skor total

$\bar{X} i \quad:$ Rata-rata skor total responden

$\bar{X} t \quad$ : Rata-rata total semua responden

$S_{t} \quad$ : Standar deviasi skor total semua responden

$P_{i} \quad$ : Proporsi jawaban yang benar untuk butir soal nomor i

$q_{i} \quad$ : Proporsi jawaban yang salah untuk butir soal nomor i

Dengan penentuan kevalidan suatu butir sebagai berikut:

Penelitian dengan $\mathrm{n}=80$, ini mempunyai $\mathrm{r}_{\text {tabel }}=0,020$ pada taraf signifikan $\alpha=0,05$ jika:

a. $\quad R_{\text {butir }}>r_{\text {tabel }}$ maka butir dianggap valid atau diterima.

b. $\quad \mathrm{R}_{\text {buti }} \leq \mathrm{r}_{\text {tabel }}$ maka butir dianggap tidak valid atau ditolak.

\subsection{Analisis Data}

\subsubsection{Uji Normalitas dan Uji Homogenitas}

Uji normalitas digunakan untuk mengetahui apakah sampel yang diteliti berasal dari populasi yang memiliki distribusi normal atau bukan. Ujinormalitas data dilakukan dengan menggunakan metode Lilifors. Dalam menentukan normal tidaknya data dengan membandingkan besarnya nilai $\mathrm{L}_{\text {hitung }}$ dengan nilai $\mathrm{L}_{\text {tabel. }}$. Apabila nilai $\mathrm{L}_{\text {hitung }}$ lebih kecil dari $\mathrm{L}_{\text {tabel }}$ maka data dinyatakan berdistribusi normal.

Uji homogenitas digunakan untuk mengetahui apakah sampel yang diteliti berasal dari populasi yang sama (homogen). Pengujian homogenitas menggunakan uji Bartlet pada taraf signifikan 5\% dengan kriteria jika $X_{\text {hitung }}^{2}<X_{\text {tabel }}^{2}$ maka data homogen.

\subsubsection{Analisis Varian}

Analisis varian (analysis of variance, ANOVA) adalah suatu metode analisis statistika yang termasuk ke dalam cabang statistika inferensi. Dalam literatur Indonesia metode ini dikenal dengan berbagai nama lain, seperti analisis ragam, sidik ragam, dan analisis variansi. Ia merupakan pengembangan dari masalah Bahrens-Fisher, sehingga uji-F juga dipakai dalam pengambilan keputusan. Analisis varian pertama kali diperkenalkan oleh Sir Ronald Fisher, bapak statistika modern. Dalam praktik, analisis varians dapat merupakan uji hipotesis (lebih sering dipakai) maupun pendugaan (estimation, khususnya di bidang genetika terapan).

Secara umum, analisis varians menguji dua varian (atau ragam) berdasarkan hipotesis nol bahwa kedua varians itu sama. Varians pertama adalah varians antarcontoh (among samples) dan varians kedua adalah varians di dalam masing-masing contoh (within samples). Dengan ide semacam ini, analisis varians dengan dua contoh akan memberikan hasil yang sama dengan uji-t untuk dua rerata (mean).

Agar sahih (valid) dalam menafsirkan hasilnya, analisis varians menggantungkan diri pada empat asumsi yang harus dipenuhi dalam perancangan percobaan:

1. Data berdistribusi normal, karena pengujiannya menggunakan uji F-Snedecor

2. Varians atau ragamnya homogen, dikenal sebagai homoskedastisitas, karena hanya digunakan satu penduga (estimate) untuk varians dalam contoh

3. Masing-masing contoh saling bebas, yang harus dapat diatur dengan perancangan percobaan yang tepat.

4. .Komponen-komponen dalam modelnya bersifat aditif (saling menjumlah). 


\section{HASIL DAN PEMBAHASAN}

\subsection{Hasil Beklajar Matematika terhadap kemandirian Belajar Tinggi (A1B1)}

A1B1 menggambarkan hasil belajar matematika mahasiswa yang diberi tes Formatif dan memiliki kemandirian belajar terhadap matematika tinggi. Banyak responden $n=13$ setelah dilakukan perhitungan statistik diperoleh nilai rata-rata $X=89.46$, modus $\mathrm{Mo}=85$, median $\mathrm{Me}$ $=88$, standar deviasi $\mathrm{s}=3.52$, varian $\mathrm{s} 2=12.37$ nilai terendah $\min =83$, nilai tertinggi $=100$ dan jangkauan range $=17$.

Data hasil belajar matematika mahasiswa yang diberi tes formatif dan memiliki kemandirian belajar terhadap matematika tinggi.

Tabel 1. Distribusi Frekuensi Hasil Belajar Matematika terhadap

Tingkat Kemandirian Tinggi.

\begin{tabular}{|c|c|c|c|}
\hline No & Nilai & Frekuensi & Frekuensi Komulatif (\%) \\
\hline 1 & $81-84$ & 1 & 7.69 \\
\hline 2 & $85-88$ & 6 & 46.15 \\
\hline 3 & $89-92$ & 3 & 23.08 \\
\hline 4 & $93-96$ & 2 & 15.38 \\
\hline 5 & $97-100$ & 1 & 7.69 \\
\hline \multicolumn{2}{|c|}{ Jumlah } & 13 & 100 \\
\hline
\end{tabular}

Histogram dari data di atas dapat disajikan sebagai berikut :

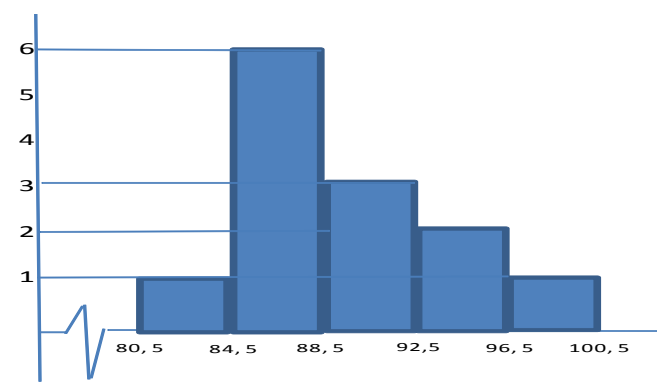

Gambar 2. Histogram hasil belajar mahasiswa terhadap tingkat kemandirian tinggi.

\subsection{Hasil Belajar Matematika terhadap kemandirian Belajar Rendah (A1B2)}

A1B2 menggambarkan hasil belajar matematika mahasiswa yang diberi tes formatif dan memiliki kemandirian belajar terhadap matematika rendah. Banyak responden $n=13$ setelah dilakukan perhitungan statistik diperoleh nilai rata-rata $X=66.85$, modus $\mathrm{Mo}=62$, median $\mathrm{Me}=$ 66 , standar deviasi $\mathrm{s}=3.36$, varian $\mathrm{s} 2=11.27$ nilai terendah $\min =60$, nilai tertinggi $=75$ dan jangkauan range $=15$.

\section{Tabel 2}

Distribusi Frekuensi Hasil Belajar Matematika terhadap Tingkat Kemandirian Rendah.

\begin{tabular}{|c|c|c|c|}
\hline No & Nilai & Frekuensi & Frekuensi Komulatif (\%) \\
\hline 1 & $58-61$ & 1 & 7.69 \\
\hline 2 & $62-65$ & 5 & 38.46 \\
\hline 3 & $66-69$ & 2 & 15.38 \\
\hline 4 & $70-73$ & 4 & 30.77 \\
\hline 5 & $74-77$ & 1 & 7.69 \\
\hline \multicolumn{2}{|c|}{ Jumlah } & 13 & 100 \\
\hline
\end{tabular}


Histogram dari data diatas dapat disajikan sebagai berikut :

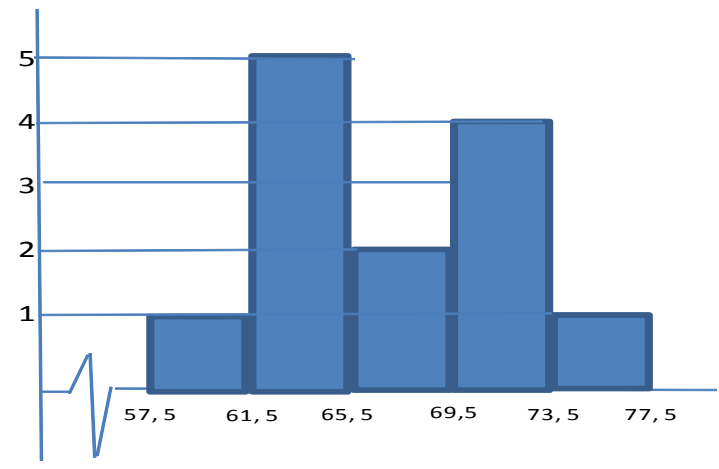

Gambar 3. Histogram hasil belajar mahasiswa terhadap tingkat kemandirian rendah.

\subsection{Interaksi Antara Kemandirian Belajar Mahasiswa dan Hasil Belajar}

Informasi interaksi antara kemandirian Belajar dan hasil belajar dapat diperoleh menggunakan ANOVA yang disajikan pada table berikut:

Tabel 3. Hasil Perhitungan ANOVA

\begin{tabular}{|c|c|c|c|c|c|c|c|}
\hline SV & $\mathrm{db}$ & \multirow{2}{*}{$\mathrm{JK}$} & $\mathrm{RK}$ & $\mathrm{Fh}$ & \multicolumn{2}{|c|}{$\mathrm{Ft}$} & \multirow{2}{*}{ Ket } \\
\hline Interaksi & 1 & 432.69 & 432 & 16.66 & 4.04 & 7.19 & $\begin{array}{c}\text { Sangat } \\
\text { Signifikan }\end{array}$ \\
\hline Dalam & 24 & 1246.77 & 25.974 & & & & \\
\hline $\begin{array}{c}\text { Total } \\
\text { Direduksi }\end{array}$ & 25 & 7916.77 & & & & & \\
\hline
\end{tabular}

a. Hipotesis:

Ho: tidak terdapat perbedaan yang signifikan antara kemandirian mahasiswa yang tinggi dan rendah dalam menghadapi tes formatif

H1: terdapat perbedaan yang signifikan antara kemandirian mahasiswa yang tinggi dan rendah dalam menghadapi tes formatif

b. Taraf signifikan : 0.05, diperoleh Ftabel $=7.19$

c. Statistik uji : Fhitung $=16.66$

d. Daerah Keputusan Ho. Ditolak Jika Fh>Fh

e. Kesimpulan: Karena Fh > Ft maka Ho ditolak

Hipotesis penelitian yang menyatakan "terdapat interaksi antara tes formatif dengan kemandirian belajar siswa", ternyata secara empiris teruji oleh data. Hal ini terlihat dari perhitungan dengan menggunakan ANOVA bahwa $\mathrm{Fh}=16.66$ ternyata lebih besar dari $\mathrm{Ft}$ yaitu 4,04. Ini berarti Ho ditolak dan H1 diterima berarti terdapat perbedaan pengaruh yang signifikan. Untuk siswa yang memiliki kemandirian belajar tinggi sangat cocok diperlukan. Penelitian ini sesuai dengan penelitian sebelumnya yang dikemukakan oleh Rahman yaitu adanya pengaruh interaksi antara tes formatif dan tingkat kemandirian belajar $\left(F_{h}=23.9\right.$ dan $F_{t}=3,910$ pada $\alpha=$ $0,05)$

\section{KESIMPULAN}

1. Kemandirian belajar mahasiswa dalam menghadapi tes formatif mempengaruhi hasil belajar matematika mahasiswa,

2. Kemandirian belajar mahasiswa yang tinggi dalam menghadapi tes formatif memiliki hasil belajar sangat baik.

3. Kemandirian belajar mahasiswa yang rendah dalam menghadapi tes formatif memiliki hasil belajar kurang baik. 


\section{Referensi}

[1] Anitah, Sri. et al. 2007. Strategi Pembelajaran Matematika. Jakarta: Universitas Terbuka

[2] Baharudin dan Esa Nur Wahyuni. 2007. Teori Belajar dan Pembelajaran. Yogayakarta: ArRuzz Media.

[3] Dimyati dan Mudjiono. 2002. Belajar dan Pembelajaran. Jakarta: Rineka Cipta.

[4] Djaali, Mulyono. 2004. Pengukuran dalam Bidang Pendidikan. Jakarta: PPS UNJ

[5] Hanun, Farida. 2009. Pengaruh Bentuk Tes Formatif dan Kemampuan Awal Mahasiswa Madrasah Terhadap Hasil Belajar Matematika. Jakarta: Jurnal pendidikan Agama dan Keagamaan. Vol. VII Nomor 2 April-Juni 2009.

[6] Leslie J. Briggs, 1993, Instructional Design Principles and Aplication, New Jersey: Englewoodcliff

[7] Lubis, Muchlis. 1987. Evaluasi Penulisan dan Cara Memperhitungkan Nilai Hasil Belajar. Jakarta: Erlangga

[8] Murwani, Santosa. 2004. Statistika Terapan. PPs UHAMKA

[9] Nazir, Moh. 2003. Metode Penelitian. Jakarta: PT. Ghalia Indonesia

[10] Ormrod, Jeabbe Ellis. 2008. Educational Psychology Learn, terjemah : Wahyu Idianti, dkk. Jakarta: Erlangga

[11] Sudjana. 2005. Metode Statistika. Bandung : PT. Tarsito

[12] Suharsimi, Arikunto. 1998. Prosedur Penelitian. Jakarta: PT. Rineka Cipta

[13] Supramono Sugiarto. 1993. Statistika. Yogyakarta: PT. Andipratita Trikarsa Mulia

[14] Stephen Brookkfield. 1983. Adult Learner Educational and The Community. SA: Teacher College Press

[15] (http://www.nwrel.org/planing/reports/self-direct/index.php) 